\title{
SEROLOGICAL STUDIES IN RHEUMATIC FEVER. II. SERUM COMPLEMENT IN THE RHEUMATIC STATE ${ }^{1}$
}

\author{
By EDWARD E. FISCHEL, 2 RUTH H. PAULI, AND JACK LESH
}

\author{
(From the Department of Medicine, Columbia University College of Physicians and Surgeons, \\ and the Edward Daniels Faulkner Arthritis Clinic of the Presbyterian \\ Hospital, New York City)
}

(Received for publication Mach 21, 1949)

In the study of rheumatic fever there has been disagreement and confusion as to the level of serum complement $\left(C^{\prime}\right)$. Veil and Buccholz (1), Coburn (2), Rachmilewitz and Silberstein (3), and others have reported a low complement content of the serum, which rises to normal with the subsidence of activity. This has been cited as possible evidence of the occurrence of an antigenantibody reaction in rheumatic fever, perhaps related to a preceding hemolytic streptococcus infection. Predominantly normal or slightly low levels of $C^{\prime}$ in rheumatic fever were reported by Kellett and Thomson (4), and more recently by deGara and Goldberg (5). On the other hand, high values during the early period of rheumatic activity and low values later were noted by Hadjopoulos and Burbank (6). In this respect, rheumatic fever did not differ from several other febrile illnesses which they studied. The variety of results obtained by different investigators may be attributed in part to the variety of technics employed, and the lack of a reproducible quantitative method. The purpose of the present study was to reevaluate complement levels in rheumatic fever with the accurate quantitative method developed by Mayer, Osler, Bier and Heidelberger $(7,8)$, in which the 50 per cent hemolytic unit is determined spectrophotometrically in the presence of adequate concentrations of $\mathrm{Mg}^{++}$and $\mathrm{Ca}^{++}$.

\section{METHOD}

Details of the analytical procedure as outlined by Mayer et al. $(8,9)$ were carefully observed since this is essential to obtain accurate and consistent results.

\footnotetext{
1 Presented at the meeting of the Eastern Section, American Federation for Clinical Research, Philadelphia, December, 1948.

2 This work was done during the tenure of a Life Insurance Medical Research Fellowship, aided in part by the Masonic Foundation Gift for the Study of Rheumatic Fever.
}

The diluent for all reagents was a barbiturate buffered sodium chloride solution (8) with the addition of $1.0 \mathrm{gm}$. magnesium chloride and $0.2 \mathrm{gm}$. of calcium chloride to the 2 liter stock solution. The stock solution was diluted 1 part up to 5 with distilled water to make an isotonic solution of $\mathrm{pH}$ 7.3-7.4. Sheep cells were obtained by sterile technic from the external jugular vein of sheep and preserved in sterile Alsever's solution (8). The suspension was kept at +2 to $+5^{\circ} \mathrm{C}$. and although some hemolysis occurred after three or four weeks, cells preserved in Alsever's solution and washed five times with buffered saline were no more fragile or susceptible to lysis than fresh cells, and yielded the same results as did washed fresh cells. After washing five times, buffered saline was added to the cells until a standardized suspension was obtained. Standardization was performed by lysing exactly $1.5 \mathrm{ml}$. of the cell suspension with $13.5 \mathrm{ml}$. of distilled water in a $15 \mathrm{ml}$. volumetric flask. The resulting solution was read in the Coleman Universal Spectrophotometer at $5500 \AA$ and, when standardized in a 13 $\mathrm{mm}$. square cuvette, gave a value of $D_{s 500}=.560$, corresponding to an original cell concentration of about 660,000 cells per cu.mm. or approximately a 2 per cent suspension. The amboceptor was rabbit serum containing antibodies to sheep red cells (Lederle) titrated for minimal hemolytic potency in the presence of an excess of $C^{\prime}$. Four minimal hemolytic units of amboceptor, an excess, were employed in each test. The amboceptor was appropriately diluted with buffered saline so that it could be mixed in exactly equal volumes with the standardized sheep cell suspension. The resulting mixture was incubated at $37^{\circ} \mathrm{C}$. for 15 minutes. On lysis of $1.5 \mathrm{ml}$. of the sensitized and standardized sheep cell suspension with $6 \mathrm{ml}$. of distilled water, a value approximating $D_{5500}=.560$ was obtained. This value, obtained in duplicate, served as the standard for the point of 100 per cent lysis and as a reference for the degree of hemolysis in the experimental tubes.

Blood was obtained from rheumatic and other individuals at the Presbyterian Hospital, Babies Hospital, and the Pelham Home for Children. After clotting at room temperature for about two hours, the blood was centrifuged for 10-15 minutes at 2,000 RPM and the supernatant serum poured off. The serum was frozen immediately and kept in the $\mathrm{CO}_{2}$ icebox until used. By storing sera in this way, repeated determinations were possible at different times and reproducible results were obtained after storage for seven months. Storage of serum in a mechanical deep freeze unit at $-17^{\circ} \mathrm{C}$. did 
not preserve the $\mathrm{C}^{\prime}$ activity. A loss of 25 to 33 per cent of the original $\mathrm{C}^{\prime}$ activity of the sera occurred in one week at this temperature.

Tests were carried out in centrifuge tubes of $40 \mathrm{ml}$. capacity to allow thorough mixing. The addition of reagents to each tube was made with analytical precision in the following order: Exactly $1.5 \mathrm{ml}$. of the standardized sensitized sheep cell suspension, buffered saline to make a final volume of $7.5 \mathrm{ml}$. after all reagents are in the tube, and serum, diluted 1 to 100 with saline, in varying quantities from 1.0 to $6 \mathrm{ml}$. Each test was performed with three different concentrations of serum. In the majority of tests, amounts of $1.5,2.0$, and $2.5 \mathrm{ml}$. of diluted serum were satisfactory. After incubation at $37^{\circ} \mathrm{C}$. for 40 minutes with frequent shaking, the tubes were centrifuged and the density of the supernates read in the Coleman Universal Spectrophotometer at $5500 \AA$. The density of the experimental tube divided by the density of a completely lysed control tube (approximately $.560)$ gave the degree of hemolysis. The amount of complement was then determined by interpolation on the curve for the equation $x=(y / 1-y)^{1 / n}$, where $x=$ the amount of complement $\left(\mathrm{C}^{\prime}\right)$ in 50 per cent hemolytic units, $y=$ the degree of lysis $(7,10)$. Preliminary tests with human complement showed that the factor $1 / n$ equalled 0.2 as it had in the determination of guinea pig complement (8). Usually two, and occasionally all three, tubes containing the various amounts of test serum gave an amount of hemolysis between 10 and 80 per cent, and could be used for interpolation of the 50 per cent unit of complement. Not only was this a control of the tech- nic at two or three different concentrations of serum, but it also permitted the detection of anticomplementary activity in the serum when increasing amounts of serum consistently showed proportionately less $\mathrm{C}^{\prime}$ activity. This situation did not occur in the series of sera reported here.

Error of technic: ${ }^{3}$ Repeated determination of the same samples of serum at different times gave values to within \pm 1.08 units of $C^{\prime}( \pm 1$ standard deviation) when the same concentration of serum was used in the repeated tests. The results of determinations at two different degrees of hemolysis (between 5 per cent and 80 per cent), e.g., with different amounts of the same serum, gave values of \pm 1.8 units, as did the results of determinations at three different degrees of hemolysis in the same hemolytic range. Since the test point employed was close to the range of 50 per cent hemolysis, the standard deviation of \pm 1.1 units is applicable to the determinations reported.

\section{RESULTS}

The mean value for the $C^{\prime}$ content of 50 normal individuals aged five to 39 was $37.7 \pm 3.950$ per cent hemolytic units per milliliter of serum. The distribution of the values in the normal subjects is

3 The writers are indebted to Dr. John W. Fertig, Professor of Biostatistics, Columbia University School of Public Health, who gave assistance in the statistical determination of the error of technic.

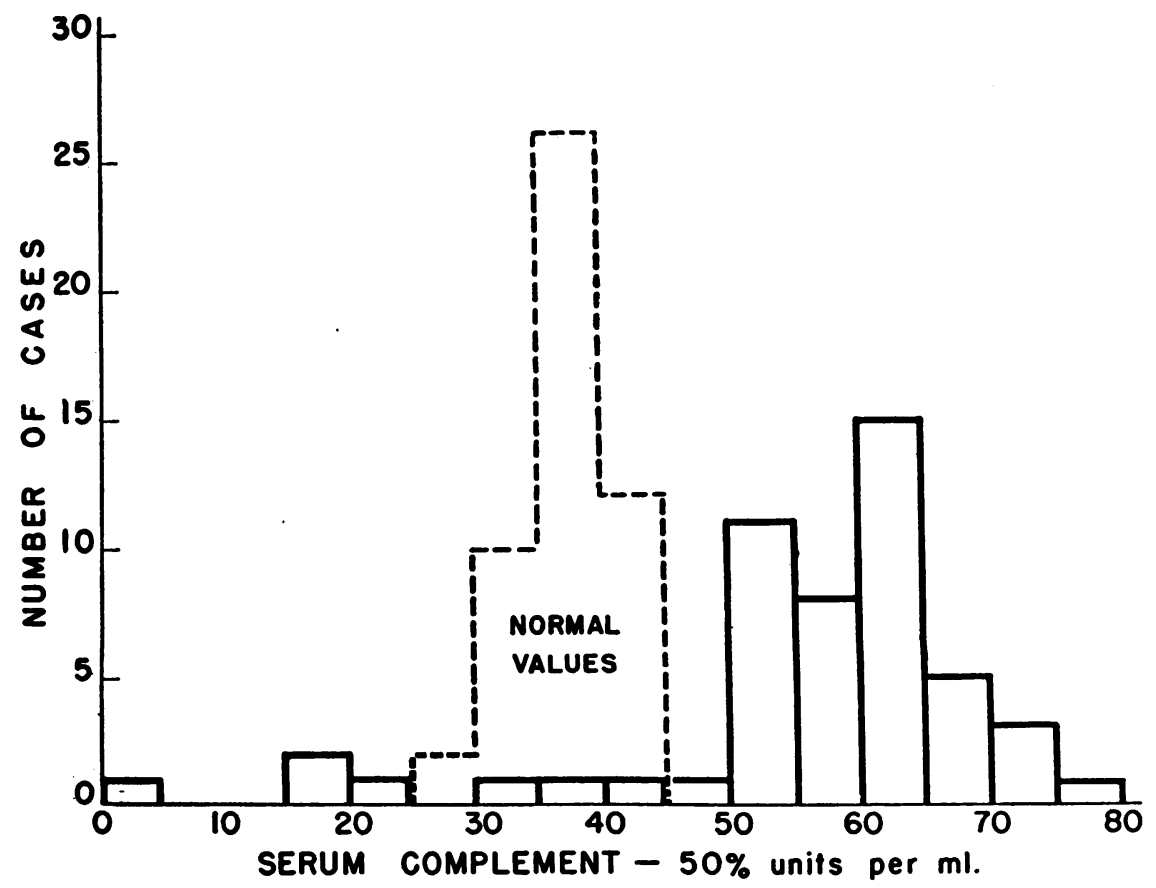

Fig. 1. Distribution of the Serum Complement of 50 Normal Individuals and Initial Levels of 50 Patients with Acute Rheumatic Fever 

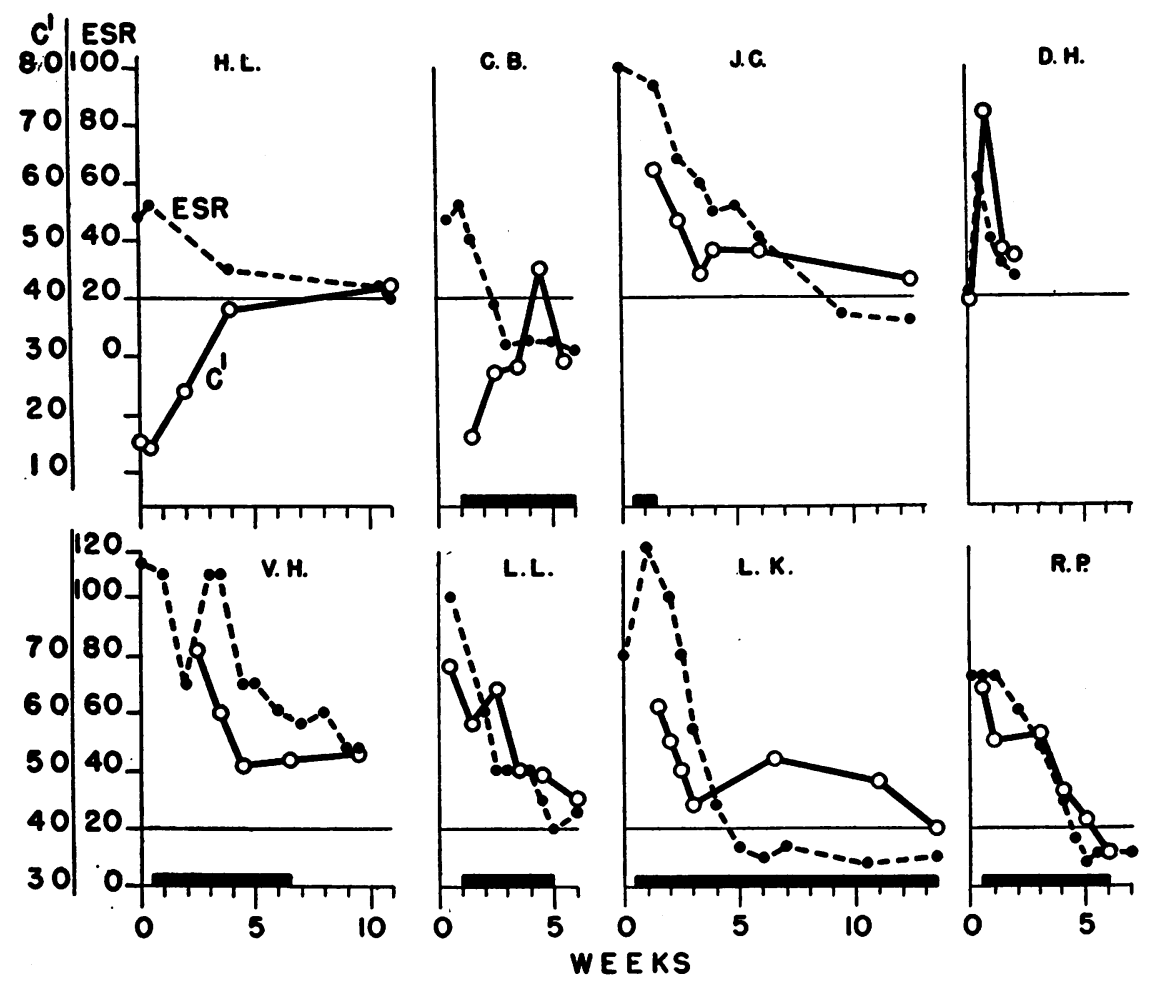

Fig. 2. Representative Curves of the $C^{\prime}$ Content During the Course of Acute Rheumatic Fever

Complement content in 50 per cent hemolytic units per milliliter of serum is charted by the open circles. The Westergren sedimentation rate (ESR) is charted by the closed circles and broken line. Heavy black lines indicate period of salicylate administration.

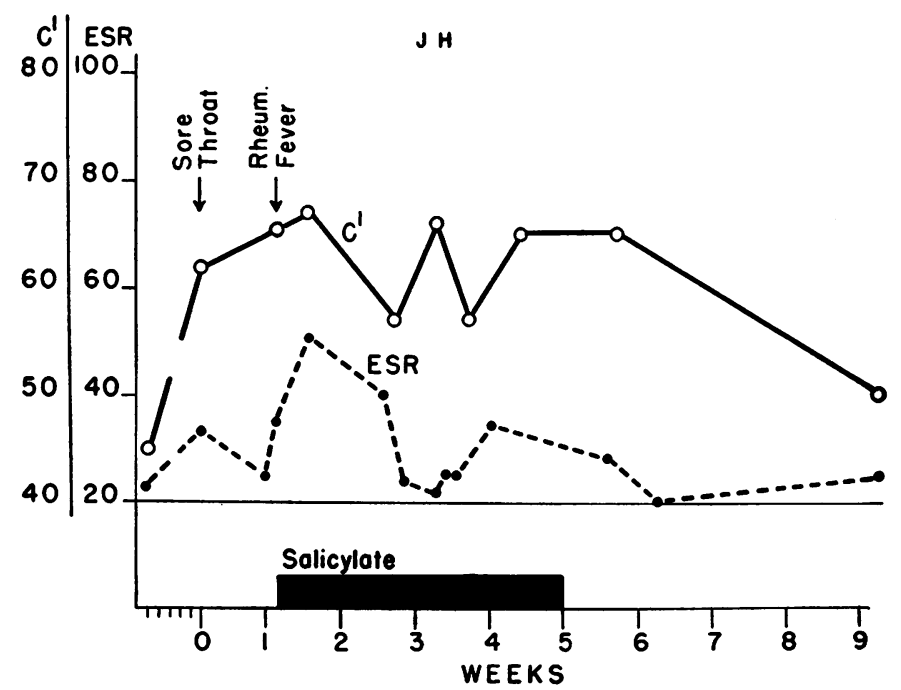

Fig. 3. Serum Complement Levels Before and During an Attack of Acute Rheumatic FeVER 
represented by the dotted bar graph in Figure 1. The $C^{\prime}$ content of the sera of normal individuals was maintained over a period of months with little variation.

Serial determinations of $C^{\prime}$ were done on the sera from 50 patients with rheumatic fever. The initial values of complement in these individuals irrespective of the duration of the active disease before coming under observation are shown in Figure 1. These values, and the subsequent determinations of $C^{\prime}$ during the course of the illness, are presented in Table I. At the time of the initial determination, the serum complement was in excess of 50 units and well above normal in 42 of the 50 patients; three others, with initially normal levels, had a subsequent elevation. Twenty-four patients were seen within two weeks after the onset of symptoms of rheumatic fever (Tables IA and B) and 20 of these had $C^{\prime}$ levels in excess of 50 units per $\mathrm{ml}$. Of the four patients seen in the first two weeks in which the level was below 50 units, one (D. H.) had a normal level on the day of onset ( 39 units). In this individual, an abrupt increase in $C^{\prime}$ was observed four days later concomitantly with the development of more manifest symptoms and an elevation of the erythro- cyte sedimentation rate. Another of the four patients seen early in the course of the disease with a $C^{\prime}$ below 50 units died shortly after a single determination revealed no $C^{\prime}$ activity. The other two patients with initial low levels $(H$. L. and C. B. in Table IB and Figure 2) presented low curves which gradually reached normal with the subsidence of activity. These two patients did not present any other unusual finding or differ clinically from the majority of patients having high complement levels. There was no evidence of an accompanying acute nephritis, as might be anticipated from the observation that several cases of acute glomerulonephritis presented low curves (11). These two patients, therefore, are the only ones which presented low $C^{\prime}$ curves. The complement curves of six other individuals are presented in Figure 2 and are representative of the curves of the 40 patients with elevated complement levels. It is apparent that complement is high initially and falls gradually to normal. This fall accompanies the subsidence of activity, as indicated roughly by the curve of the erythrocyte sedimentation rates (millimeters after one hour, Westergren method). Although many patients developed a rise in antistreptolysin " $O$ " titers, there was no correlation

TABLE IA

Total serum complement in rheumatic fever related to the stage of the disease Cases seen before and during acute exacerbation of rheumatic fever

\begin{tabular}{|c|c|c|c|c|c|c|c|}
\hline \multirow{3}{*}{ Patient } & \multirow{3}{*}{\multicolumn{2}{|c|}{$\begin{array}{l}\text { Complement before the attack } \\
50 \text { per cent units per ml. serum }\end{array}$}} & \multirow{2}{*}{\multicolumn{4}{|c|}{$\begin{array}{c}\begin{array}{c}\text { Complement after the attack } \\
50 \text { per cent units }\end{array} \\
\text { Week of disease }\end{array}$}} & \multirow{3}{*}{ Comments } \\
\hline & & & & & & & \\
\hline & & & \multirow{2}{*}{$\frac{\text { Onset }}{64}$} & \multirow{2}{*}{$\frac{2 n d}{67}$} & \multirow{2}{*}{$\frac{3 r d}{57,66}$} & etc. & \\
\hline J. H. & $\begin{array}{l}1 \text { mo. before sore throat } \\
\text { Sore throat } 1 \mathrm{wk} \text {. before the } \\
\text { attack }\end{array}$ & $\begin{array}{l}43 \\
62\end{array}$ & & & & $\begin{array}{c}57,65,65 \ldots \\
\ldots \ldots 50\end{array}$ & Charted in Figure 3 \\
\hline A. N. G. & 1 wk. before recrudescence & 52 & 51 & 48 & 26 & $30,38,50,45$ & Biphasic curve \\
\hline A. $\mathrm{S}$. & 4 wks. before recrudescence & 39 & 60 & 42 & 43 & & Charted in Figure 4 \\
\hline H. G. & $\begin{array}{l}2 \text { mos. after subsidence of } \\
\text { clinical activity. (ESR } * 14)\end{array}$ & 50 & $60 \dagger$ & $70 \dagger$ & & & $\begin{array}{l}\text { Died of rheumatic } \\
\text { myocarditis } 2 \text { mos. } \\
\text { after last determina- } \\
\text { tion }\end{array}$ \\
\hline A. A. & 2 mos. before recrudescence & $\begin{array}{l}36 \\
42\end{array}$ & 53 & 48 & 64 & $62,60,44,50$ & \\
\hline J. M. & $\begin{array}{l}6 \text { wks. before recrudescence } \\
4 \text { wks. before recrudescence } \\
2 \text { wks. before recrudescence }\end{array}$ & $\begin{array}{l}37 \\
52 \\
48\end{array}$ & 60 & & 41 & $\begin{array}{l}41 \\
\text { after } 1 \mathrm{mo} .\end{array}$ & Charted in Figure 4 \\
\hline
\end{tabular}

* Westergren sedimentation rate.

t Asymptomatic but ESR suddenly 100 . 
TABLE IB

Cases seen within two weeks of onset of acute rheumatic fever

\begin{tabular}{|c|c|c|c|c|c|c|c|c|}
\hline \multirow{3}{*}{ Patient } & \multirow{3}{*}{$\begin{array}{l}\text { Duration of } \\
\text { illness before } \\
\text { observation }\end{array}$} & \multicolumn{6}{|c|}{ Complement content of serum 50 per cent units per ml. } & \multirow{3}{*}{ Comment } \\
\hline & & \multicolumn{6}{|c|}{ Weeks under observation } & \\
\hline & & 1 & 2 & 3 & 4 & etc. & & \\
\hline D. H. & 1 day & 39 & 76 & & 48 & & & $\mathrm{C}^{\prime}$ paralleled rise and fall of ESR \\
\hline A. $\mathrm{Ek}$. & 1 day & 76 & & 66 & & & & \\
\hline V. Jam. & 1 day & 56,68 & 67 & 75 & & 57 & 43 & \\
\hline V. Ro. & 2 days & 50 & & 42 & & & 35 & \\
\hline M. P. & 2 days & 70 & 72 & 60 & 53 & 45 & 45 & $\begin{array}{r}\text { Developed chronic activity for } 4 \\
\text { mos. with } C^{\prime} \text { of } 49 \text { to } 53 \text {, then } 40\end{array}$ \\
\hline T. W. & 2 days & 62 & 71 & & & & & \\
\hline H. L. & 3 days & 15,14 & & 24 & & 38 & 42 & Low curve \\
\hline C. B. & 5 days & 17 & 27 & & 28 & 45 & 29 & $\begin{array}{l}\text { Developed chorea } \\
\text { Low curve at onset and later }\end{array}$ \\
\hline L. L. & 5 days & 67 & 58 & 64 & 49 & 49 & 45 & Mild thyrotoxicosis after third week \\
\hline G. Je. & 5 days & 63 & 75 & 66 & 53 & 50 & 50 & Continued activity \\
\hline L. F. & $1 \mathrm{wk}$. & 63 & 66 & 63 & 59 & 48 & & \\
\hline L. K. & 1 wk. & 61 & 55 & 50 & 44 & $52 \quad 48$ & 40 & \\
\hline R. Ag. & 1 wk. & 55 & & & 47 & & & \\
\hline A. See & 1 wk. & 62 & & 50 & & & & \\
\hline J. Cam. & 1 wk. & 62 & 53 & 44 & 48 & 48 & 43 & \\
\hline N. Fa. & 2 wks. & 0 & & & & & & $\begin{array}{l}\text { Died } 3 \text { days later; acute pulmon- } \\
\text { ary edema }\end{array}$ \\
\hline F. Aco. & 2 wks. & 56 & 52 & 80 & 70 & 80 & & Discharged active \\
\hline J. Bar. & 2 wks. & 63 & 50 & 55 & & 40 & 46 & \\
\hline
\end{tabular}

with the rise and fall of serum complement content.

Six patients have been observed with complement determinations before a recrudescence of rheumatic activity (Table IA and Figures 3 and 4). An elevation of serum $C^{\prime}$ frequently preceded the onset or exacerbation of rheumatic activity either as a sequence of a sore throat, or as a manifestation of continuing subclinical rheumatic activity. The change in complement activity from the relatively normal state, with the onset of a hemolytic streptococcus infection and, subsequently, of rheumatic fever is seen in Figure 3. The patient, J. H., was being observed routinely in the follow-up clinic seven years after an attack of rheumatic fever and had a mild upper respiratory infection due to an undetermined organism. Two months later, the patient experienced a streptococcus sore throat. The sedimentation rate rose, as did the complement level. With the occurrence of acute rheumatic fever ten days later, the serum complement remained elevated, with renewed elevation of the sedimentation rate. Observations to be reported show that many acute inflammatory illnesses such as acute pharyngitis are accompanied by an increase of serum complement (11). This increase abruptly subsides except in the few instances where active infection persists or, as in this instance, rheumatic fever develops. The character of $C^{\prime}$ levels in recurrent rheumatic attacks is also illustrated in the chart of three patients presented in Figure 4. These 
children had had activity three to six months before the initial $C^{\prime}$ determinations. Despite the apparent subsidence of activity by the usual clinical and laboratory criteria at least three months previously, the first two children, J. M. and A. S., were kept on salicylates. Salicylate was then discontinued with recurrent manifestations of activity in both children. In the first patient, the $C^{\prime}$ was elevated before cessation of the salicylate and, in retrospect, can be considered an indication of continuing subclinical rheumatic activity. In the second individual a normal $\mathrm{C}^{\prime}$ was present at the time salicylate was discontinued but was elevated four weeks later. In the subsequent recrudescence, if such it may be called, no joint flare-ups, fever, or tachycardia accompanied the rise in sedimentation rate and $C^{\prime}$. The third individual, H. G., had had an acute attack of rheumatic fever, which subsided promptly. The first observation of complement was done after discharge from the hospital and was somewhat elevated but the sedimentation rate was normal. After two months the ESR and $C^{\prime}$ were observed to be elevated and a tachycardia developed. No other manifestations were ob-

TABLE IC

Cases of rheumatic fever seen two or more weeks after onset

\begin{tabular}{|c|c|c|c|c|c|c|c|}
\hline \multirow{2}{*}{ Patient } & \multirow{2}{*}{$\begin{array}{c}\text { Duration of } \\
\text { illness before } \\
\text { observation }\end{array}$} & \multicolumn{5}{|c|}{ Weeks under observation } & \multirow{2}{*}{ Comment } \\
\hline & & 1 & 2 & 3 & 4 & etc. & \\
\hline V. H. & 3 wks. & 71 & 60 & 51 & 52 & 53 in 15 th wk. & $\begin{array}{l}\text { Developed thyrotoxi- } \\
\text { cosis }\end{array}$ \\
\hline R. P. & 3 wks. & 65 & 55 & & $56,46,41$ & 35 in 9th wk. & \\
\hline S. Cr. & 3 wks. & 41 & 53 & 38 & & & Subsiding activity \\
\hline R. Mc. & 3 wks. & 22 & & & & & Died 6 wks. later \\
\hline L. Go. & 3 wks. & 56 & 57 & 56 & 49,49 & 50 & \\
\hline M. E. & 3 wks. & 64 & & 50 & & & \\
\hline M. Do. & 3 wks. & 50 & 48 & 43 & & 44 & \\
\hline J. Cul. & 3 wks. & 52 & 46 & 30 & & & Died in 4th week \\
\hline D. Pa. & 4 wks. & 66 & & 50 & 50 & 32 in 10 th wk. & \\
\hline M. So. & 4 wks. & 61 & 63 & 53 & 54 & & Discharged active \\
\hline M. Con. & 4 wks. & 52 & 42 & & $\begin{array}{c}39 \\
\text { inactive }\end{array}$ & 39 & \\
\hline B. W. & 4 wks. & 65 & 49 & 56 & 49 & 59 & Discharged active \\
\hline A. $\mathrm{K}$. & 4 wks. & 55 & 55 & & 29 & 42 after 2 mos. & \\
\hline V. Ack. & 5 wks. & 48 & 50 & 49 & 56 & 43 & \\
\hline T. Tho. & 5 wks. & 50 & & 45 & 50 & 52 & Continues active \\
\hline A. Ada. & 5 wks. & 53 & & & & & \\
\hline C. Bre. & 5 wks. & 51 & 53,47 & 37 & 39 & 33 & \\
\hline H. Am. & 2 mos. & 32 & & 29 & & $\begin{array}{l}5 \text { mos. later } 37 \\
\text { (inactive) }\end{array}$ & \\
\hline J. A. M. & 5 mos. & 73 & & & & $\begin{array}{l}37 \\
\text { quiescent } 3 \text { mos. } \\
\text { later }\end{array}$ & \\
\hline R. Mad. & $\begin{array}{l}6 \text { mos. } \\
\text { Low-grade } \\
\text { activity }\end{array}$ & 51 & 54 & & & & \\
\hline
\end{tabular}


TABLE ID

Chronically active rheumatic fever

\begin{tabular}{|c|c|c|c|c|c|c|c|}
\hline \multirow{2}{*}{ Patient } & \multirow{2}{*}{$\begin{array}{c}\text { Duration of } \\
\text { illness before } \\
\text { observation }\end{array}$} & \multicolumn{5}{|c|}{ Weeks under observation } & \multirow{2}{*}{ Comment } \\
\hline & & 1 & 2 & 3 & 4 & etc. & \\
\hline M. Me. & 2 mos. & 64 & 52 & 57 & 41 . & 56 & $\begin{array}{l}\text { Rise with reactiva- } \\
\text { tion }\end{array}$ \\
\hline V. Be. & 3 mos. & 60 & & & & & \\
\hline B. Ma. & 8 mos. & 65 & & & 55 & 54 & $\begin{array}{l}\text { Recurrent nodules, } \\
\text { elevated, sed. rate }\end{array}$ \\
\hline McR. & 8 mos. & 55 & & & 53 & & \\
\hline N. Cl. & 18 mos. & 58 & 58 & & & & \\
\hline A. Ei. & 4 yrs. & 51 & 53 & 46 & 54 & 54 after 4 mos. & \\
\hline
\end{tabular}

served at that time. Subsequently, a fulminating attack of acute rheumatic myocarditis developed which terminated with death two months later. It is probable that the initial observation of an elevated $\mathrm{C}^{\prime}$ in this instance indicated continued subclinical activity, later becoming manifested by an elevated sedimentation rate as well, and then tachycardia, fever and frank myocarditis.
The presence of subclinical activity was also detected in the patient, A. A., of Table IA. This patient had had a rheumatic attack with prompt subsidence of activity two months previous to the first observation. The sedimentation rate was normal as was the complement content of the serum. Without any clinical changes, and with a continued normal sedimentation rate, the $C^{\prime}$ rose

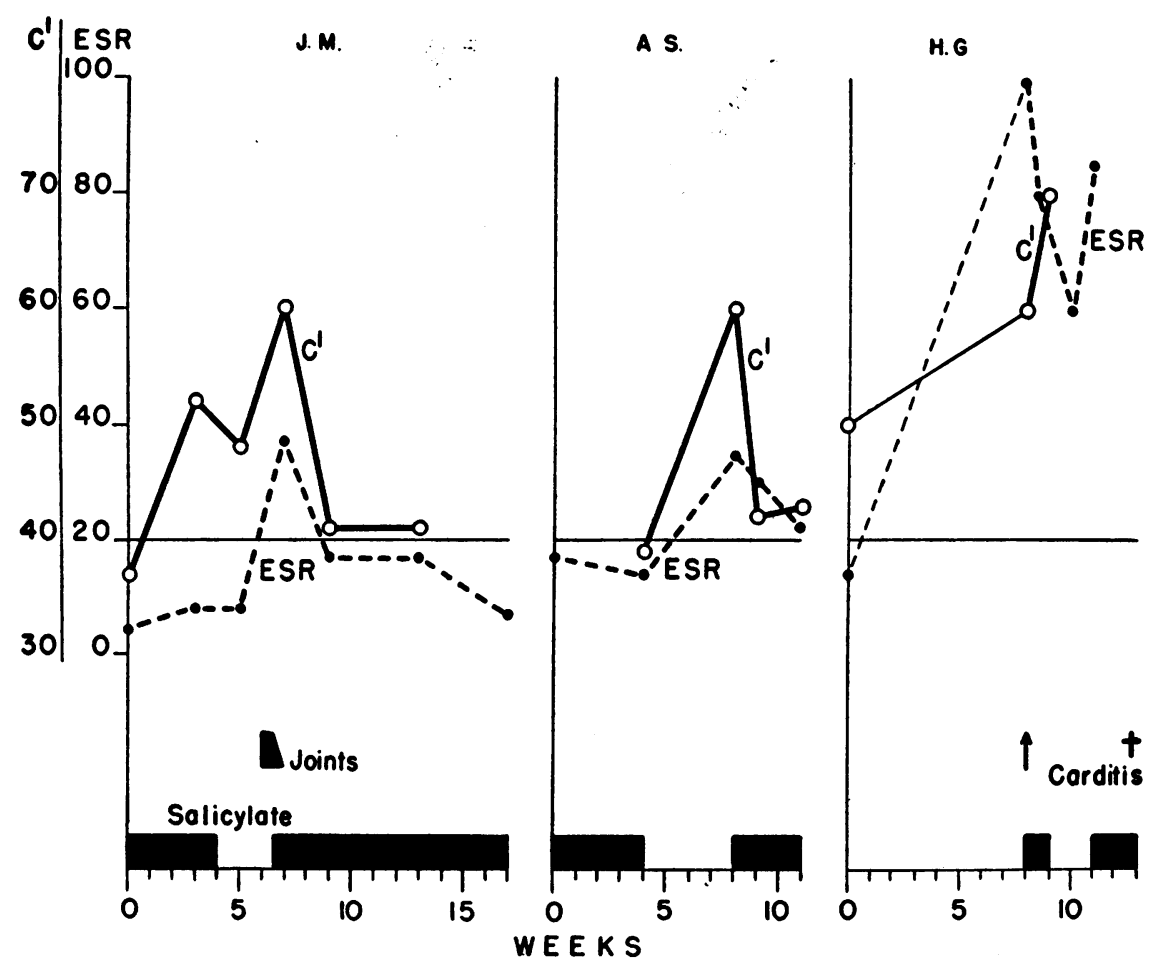

Fig. 4. The Complement and Sedimentation Rate of Three Patients with Recurrent Rheumatic Fever Who Had Had Subsidence of Clinical Activity Three to Six Months Previously 
after one month to 53 units and later to 64 . After four weeks of unexplained elevation of the serum complement a moderate but persistent tachycardia was observed and an abrupt elevation of the sedimentation rate occurred.

\section{DISCUSSION}

Serum complement has been of interest to many investigators who attempted to define the rheumatic state as an allergic type of reaction $(1-3,12)$. A diminution of circulating complement is found in certain experimental antigen-antibody reactions, both in vitro (13) and in vivo (14). Clinically, a diminution of serum complement has been reported in some cases of serum sickness $(11,15$, 16). However, there are several causes for a low $\mathrm{C}^{\prime}$ other than fixation by antigen-antibody aggregates. Decreased production of $\mathrm{C}^{\prime}$ is said to occur in liver disease (17), and in terminal illnesses (18). Also, $\mathrm{C}^{\prime}$ levels apparently may be diminished by the presence of inhibitory or anticomplementary substances in the serum. Anticomplementary sera are occasionally found in routine Wassermann tests, but the nature of the substances responsible for the inhibition or inactivation of complement is not clear. One such substance is gamma globulin, a relative preponderance of which causes serum to become anticomplementary (19). This study, employing a precise and reproducible technic, failed to confirm the reports of a low complement in 46 of 50 cases of rheumatic fever. Of four cases with a low $C^{\prime}$ content, two died shortly after the determination. The observation is in agreement with previous reports $(17,18)$ of a low $\mathrm{C}^{\prime}$ preceding death in many conditions other than rheumatic fever. Two patients with rheumatic fever exhibited low complement curves (Figure 2, H. L. and C. B.). No evidence of an abnormal anticomplementary effect was found in the sera of these patients to account for the low $\mathrm{C}^{\prime}$ activity but the diminution may have been due to an antigen-antibody reaction that occurred independently of the rheumatic process.

It is known that certain antigen-antibody reactions do not fix complement in vitro (20). In addition, in several known allergic reactions, with clinical manifestations similar to serum sickness, but caused by a simple chemical antigen, e.g., sulfadiazine, a high complement level was found (11). Because these immunologic or allergic reactions may occur without any apparent fixation or diminution in complement, the possibility remains that the rheumatic reaction may be allergic and yet fail to fix complement. It is therefore apparent that the allergic hypothesis for the development of rheumatic fever receives neither support nor refutation by the data presented, although evidence for the occurrence of an antigen specific for rheumatic fever has not been substantiated (21).

This study fails to confirm reports of a low or normal $C^{\prime}$ in patients with rheumatic fever. Indeed, an unexpected finding in the opposite direction was observed. An increase in $C^{\prime}$ above 50 units per milliliter was observed at some time in 45 of the 50 cases observed. The increase was particularly marked early in the course of the disease. Very few reports in the literature mention an increase in $\mathrm{C}^{\prime}$ in acute inflammatory disorders $(6,22)$, possibly because the customary use of double dilution of serum (viz., .01, .02, .04 ml. with a normal value of $0.02 \mathrm{ml}$.), does not permit increased $\mathrm{C}^{\prime}$ activity to be noted except where the increase is 100 per cent or more above normal. In addition, maximal $\mathrm{C}^{\prime}$ activity may have been prevented by the lack of optimal concentrations of $\mathrm{Mg}^{++}$and $\mathrm{Ca}^{++}(8)$. Using the technic of Mayer et al., a high $\mathrm{C}^{\prime}$ was also found in a variety of other acute and chronic illnesses (11). The cause for the increase in $C^{\prime}$ activity is not apparent. Although the complement response in rheumatic fever does not appear to be specific for this disease, the mechanism of this increase warrants further study, as it may be concerned with resistance mechanisms. Serum complement is a complex of labile substances which apparently plays a part in resistance mechanisms of the host. It is instrumental in promoting phagocytosis of bacteria and probably has a wide range of more illdefined activities $(17,23-25)$. The increase in $C^{\prime}$ in inflammatory conditions resembles somewhat other non-specific changes in the blood such as the elevation of the sedimentation rate and the appearance of the C-reactive protein of Tillett and Francis (26) (the acute phase protein).

The elevation of complement in most cases of rheumatic fever is related to the course of the disease. It may remain abnormally elevated with apparent subsidence of activity and the return to normal of other criteria such as the polymorphonuclear leukocyte count or the ESR. In these in- 
stances it appears to be a more sensitive indication of continuing activity than the ESR. However, it is not an infallible aid because it, as well as the sedimentation rate, may occasionally be normal a few days before obvious clinical exacerbation occurs. Furthermore, the extent of increase in complement does not appear to be related to the severity of the disease process but may perhaps be related to the abruptness of the change from the normal to the pathological state. Further studies concerning the relationship of an increased $\mathrm{C}^{\prime}$ content of serum to activity of the rheumatic process are in progress.

\section{SUMMARY}

1. Quantitative serial studies of total complement $\left(C^{\prime}\right)$ in serum were made, using the spectrophotometric technic for the determination of the 50 per cent hemolytic unit in the presence of magnesium and calcium ions.

2. The range of complement in sera of 50 normal individuals was found to be $37.7 \pm 3.9$ units per milliliter.

3. Forty-five of 50 patients with rheumatic fever had an elevation of the serum complement above 50 units per milliliter of serum at the onset of the attack or shortly thereafter. Two patients presented a low complement which gradually became normal. Of the remaining patients, two others had a low $\mathrm{C}^{\prime}$ and died, and one patient had a normal $C^{\prime}$ level determined when the disease process was beginning to subside.

4. The elevation of serum complement appears to be another criterion of activity of the rheumatic process.

5. The relationship of these observations to the hypothesis that the rheumatic state is of allergic origin is discussed.

\section{ACKNOWLEDGMENTS}

The authors are indebted to Dr. M. Heidelberger, Dr. E. A. Kabat, Dr. M. Mayer and Dr. A. Osler for their guidance and criticism.

\section{BIBLIOGRAPHY}

1. Veil, W. H., and Buccholz, B., Der Komplementschwund im Blute. Klin. Wchnschr., 1932, 11, 2019.

2. Coburn, A. F., Observations on the mechanism of rheumatic fever. Lancet, 1936, 2, 1025.
3. Rachmilewitz, M., and Silberstein, W., The amount of complement in the blood in rheumatic fever and rheumatoid arthritis. J. Lab. \& Clin. Med., 1937, 22, 1240.

4. Kellett, C. E., and Thomson, J. G., Complementary activity of blood serum in nephritis. J. Path. \& Bact., 1939, 48, 519.

5. deGara, P. F., and Goldberg, H. P., Immunologic and biochemical studies in infants and children with special reference to rheumatic fever. III. Complement titers in abnormal conditions. $\mathrm{Pe}-$ diatrics, 1948, 2, 248.

6. Hadjopoulos, L. G., and Burbank, R., The rôle of complement in health and disease. J. Lab. \& Clin. Med., 1928, 14, 131.

7. Mayer, M. M., Eaton, B. B., and Heidelberger, M., Spectrophotometric standardization of complement for fixation tests. J. Immunol., 1946, 53, 31.

8. Mayer, M. M., Osler, A. G., Bier, O. G., and Heidelberger, M., The activating effect of magnesium and other cations on the hemolytic function of complement. J. Exper. Med., 1946, 84, 535.

9. Kabat, E., and Mayer, M. M., Immunochemistry. Charles C. Thomas, Springfield, Ill., 1948.

10. von Krogh, M., Colloidal chemistry and immunology. J. Infect. Dis., 1916, 19, 452.

11. Fischel, E. E., unpublished observations.

12. Fischel, E. E., The rôle of allergy in the pathogenesis of rheumatic fever. Am. J. Med., in press.

13. Bordet, J., and Gengou, O., Sur l'existence de substances sensibilisatrices dans la plupart des sérums antimicrobiens. Ann. de l'Inst. Pasteur, 1901, 15, 289.

14. Friedberger, E., and Hartoch, O., Ueber das Verhalten des Komplements bei der aktiven und passiven Anaphylaxie. Ztschr. f. Immunitätsforsch. u. exper. Therap., 1909, 3, 581 (orig.).

15. Francioni, C., La diminuzione del complemento nella malattia de Siero. Riv. di clin. pediat., 1908, 6, 321.

16. Rutstein, D. D., and Walker, W. H., Complement activity in pneumonia. J. Clin. Invest., 1942, 21, 347.

17. Osborn, T. W. B., Complement or Alexin. Oxford Univ. Press, London, 1937.

18. Longcope, W. T., Study of the bacteriolytic serum complements in disease; a contribution to our knowledge of terminal and other infections. J. Hyg., 1903, 3, 28.

19. Davis, B. D., Kabat, E. A., Harris, A., and Moore, D. H., The anticomplementary activity of serum gamma globulin. J. Immunol., 1944, 49, 223.

20. Goodner, K., and Horsfall, F. L., Jr., The complement fixation reaction with pneumococcus capsular polysaccharide. J. Exper. Med., 1936, 64, 201.

21. Fischel, E. E., and Pauli, R. H., Serological studies in rheumatic fever. I. The "phase" reaction and 
the detection of autoantibodies in the rheumatic state. J. Exper. Med., 1949, 89, 669.

22. Ecker, E. E., Seifter, S., Dozois, T. F., and Barr, L., Complement in infectious disease in man. J. Clin. Invest., 1946, 25, 800.

23. Heidelberger, M., Complement: immunity intensifier, diagnostic drudge, chemical curiosity. American Scientist, 1946, 34, 597.
24. Pillemer, L., Recent advances in the chemistry of complement. Chem. Rev., 1943, 33, 1.

25. Ecker, E. E., and Lopez-Castro, G., Complement and opsonic activities of fresh human sera. $\mathrm{J}$. Immunol., 1947, 55, 169.

26. Tillett, W. S., and Francis, T., Jr., Serological reactions in pneumonia with a non-protein somatic fraction of pneumococcus. J. Exper. Med., 1930, 52,561 . 